\title{
The Implementation and Evaluation of the United States Affordable Care Act
}

\author{
DAVID SCHULTZ
}

\begin{abstract}
In 2010 the United States Congress adopted the Patient Protection and Affordable Care Act ("ACA"), more commonly referred to as Obamacare. The ACA was proposed by President Barack Obama while running for president and it was passed with a near straight partyline vote of Democrats in the US House and Senate in 2010. The ACA was meant to address several problems with the American health care delivery system, including cost, access and outcomes. This article describes the major features of the ACA including the context of the US health care system, evaluates the ACA's implementation history and assesses its fate and future reforms throughout the presidency of Donald Trump. The overall conclusion based on its implementation is that while the ACA made significant reforms in terms of access to health care, it is not clear that it addressed affordability or began to improve health care outcomes in the US.
\end{abstract}

Keywords: • United States $•$ Health Care Reform $•$ Affordable Care Act - Obamacare •

Correspondence Address: David Schultz, PhD, Associate Professor, Hamline University, Department of Political Science, MS B 1805 B, 1536 Hewitt Avenue, Saint Paul, Minnesota, USA 55105, e-mail: dschultz@hamline.edu. 


\section{Introduction}

The key to understanding health care policy and reform in the United States resides in understanding three basic precepts. First, there is no single health care policy in America; instead, there is a highly decentralized and fragmented delivery system that involves a variety of public, private and non-profit (NGO) players operating in an environment that crosses several layers of government. Second, health care in the United States is neither a constitutional nor a legal right. Instead, health care is provided pursuant to two basic delivery systems: a private, market driven for profit system based on the ability to pay; and, a public system offered by the government to individuals free or at reduced cost for those who meet specific statutory requirements. Third, despite recent reforms that have extended coverage to more individuals, statutory changes in eligibility can only go so far in terms of improving public health. That is to say, simply providing more health services to more people is only one part of a larger public health puzzle that also requires addressing other issues such as the overall cost and quality of medical services, and also other policy issues such as poverty, pollution, domestic violence and crime.

These three precepts are significant because they help explain not only the history of health care policy in the United States, but they also clarify and set the context for recent reforms in America. Specifically, in 2010 the United States Congress adopted the Patient Protection and Affordable Care Act (also known as the Affordable Care Act or "ACA"), more commonly referred to as Obamacare by the public. The ACA was an initiative proposed by President Barack Obama while running for president and it was passed with a near straight party-line vote of Democrats in the US House and Senate in 2010. The ACA received only one vote from the opposition Republican Party. The ACA remains very controversial, with those supporting and disapproving of it following mostly along partisan lines. Most Democrats and those who identify with that political party support it, with most Republicans office holders opposing it. Since its adoption in 2010, there have been continual efforts by those opposed to it to repeal the ACA. Those efforts have included constitutional attacks in the courts, together with other efforts to block its implementation, and at the very least dismantling it step by step.

Firstly, this article describes the major features of the ACA, evaluates its implementation history and attempts to forecast its fate and future reforms under the presidency of Donald Trump. To provide context for the adoption of the ACA, this article also will briefly describe the origins, evolution and structure of the American health care delivery system. Second, the article then describes the state of health care policy in America, concentrating upon issues of cost, coverage, access and outcomes. The purpose here is to clarify the political and policy environment behind the 2010 reforms. Third, the article will describe the passage of the ACA and will outline the main provisions of the law. The last section describes what has happened to the ACA since adoption, concentrating upon its implementation and legal challenges in the first two years of the Trump presidency. The overall conclusion is that while the ACA made significant reforms in terms of access, it remains unclear whether it has sufficiently addressed problems with the overall affordability of health care and 
whether it has improved health care outcomes for citizens of the US. Finally, with a politically divided county, it is also not clear what the future of the ACA will be or what reforms are on the political horizon.

History of US Health Care Policy to 2008

\subsection{Health Care in the US from the Nineteenth Century to WW II}

Before the end of World War II, there was largely no federal or national health care policy or system in the United States. The simplest way to describe the historic origins of health care policy in the United States is to state that for approximately the first 150 years of the country's existence there were no uniform health care policies either at the federal (national) or state levels. Instead, health care was provided either on an individual, fee-for-service approach or through charity. Paul Starr (1982: 20-22) has written that the delivery of health care and the formulation of policies surrounding it have to a large extent been shaped by the American medical profession and the American Medical Association (hereinafter "AMA") who created the delivery of health care services based on fee- for-services rendered.

As Starr points out, the transformation of the American economy, especially in urban areas, began creating a market for a fee-for-services delivery of health care. In other words, doctors would provide health care services to patients who could afford to pay for it. Health care delivery became a commodity or service that would be sold for a fee. Individuals lacking the ability to pay would not receive medical coverage. Doctors, who formed the AMA in 1847 (formally incorporated in 1897), were central to defining how the health care delivery market would develop (Hillstrom, 2012: 48).

The twentieth century witnessed several changes in health care policy in America. The first major development was passage by Congress in 1906 of the Pure Food and Drug Act. This Act, a major piece of consumer legislation, sought to protect the public from adulterated food and unsafe drugs. The Act both required the listing of drugs contained in products and also regulated certain dangerous drugs. The 1906 Act was the predecessor to the 1938 Federal Food, Drug, and Cosmetic Act, which gave the federal government the ability to regulate drugs for medical use.

A second major development was the emergence in the United States of private health care insurance prior to World War II. In 1883, Germany became the first country in the world to provide for sickness or illness insurance. Other countries soon followed, including Sweden in 1891, the United Kingdom in 1911, and Russia in 1912 (Starr, 1982: 237). The reasons why these countries began offering such insurance is varied, with some arguing that the strength of the social democratic and communist movements in these countries forced these governments to offer insurance as a means of "buying off" workers and reaching economic and social peace. Conversely, the reasons for why a public insurance system did not develop at this time in the United States had much to do with the strength of the AMA and physicians who prized autonomy, feared government regulation and socialism, and saw a government insurance system as a threat to their livelihood. 
What did change the debate on health care insurance and delivery in the United States was the 1930s Great Depression and World War II. The Great Depression led to the election of President Franklin Roosevelt whose New Deal legislation ushered in many social welfare programs for the poor and especially the middle class. More importantly, the United States' entrance into World War II transformed America's health care in a critical way. During the war, the United States government instituted wage and price freezes and many regulations. In short, employers were prohibited from increasing wages unless approved by the government. Given the war time civilian labor shortages, private businesses had to find some way to attract workers. What they offered them was health care insurance (Hillstrom, 2012: 218). This employer-provided health care insurance, which often was free of charge to the workers, led to a rapid growth in the number of individuals insured. The rise of private or voluntary employer-provided health care insurance arose simultaneously with the growth and development of for-profit insurance companies.

The genesis and development of for-profit health insurance provided a major impetus for the expansion of health care delivery, including the rapid expansion and creation of hospitals. It would not be hyperbole to declare that by the end of World War II American medicine had been remade into an increasingly corporate enterprise with significant for-profit businesses providing either health care insurance or the actual delivery of services, or both. Couple this emergence of a corporate, yet physician dominant health care system, along with an expansion of services for the military, and the basic structure of the American health care delivery system was strongly rooted in society.

Accordingly, by the time World War II ended, the basic structure of the American health care delivery system was in place. It included a separation of insurance from the actual delivery of health care, but with both remaining primarily in private control. With the small exception of charity care and some services provided for the military and veterans, health care was delivered on a fee-for-service market model where physicians enjoyed a significant amount of autonomy to provide treatment. Finally, as a consequence of World War II, health care insurance was offered by employers as a result of the employment relationship and not provided either as a universal condition of American citizenship or on the basis of medical need.

\subsection{Harry Truman and the Call for National Health Insurance}

Health care policy in the United States significantly evolved immediately after the end of World War II, laying the foundation for policy debates and reform that would continue to affect the United States up to the present. One seminal development was President Harry Truman's call for universal health care coverage in 1945. The second was passage of the Hill-Burton Act in 1946. 
In 1944 President Roosevelt called for an economic bill of rights that included a right to medical care (Hillstrom, 2012: 289-292; Starr, 1982: 280). However, Roosevelt soon died after election to his fourth term, leaving his vice-president Harry Truman to succeed him. In a November 1945 speech, Truman called for the creation of a national health care program (Starr, 1982: 281).

The context of the speech was military preparedness. Truman noted that many individuals who were drafted or volunteered for the armed forces were too sick to serve or had physical problems that adversely affected their readiness for military duty. Truman's speech was a clarion call for better delivery of medical services and it inspired passage of the Hill-Burton Act and hospital construction and other expansions of health care services. But the most important part of the speech-the call for universal health care insurance for all-would become a defining policy objective for many political liberals and Democrats, including Massachusetts Senator Ted Kennedy, up to and through the passage of the ACA in 2010.

The quest for expansion and universal health care insurance in the United States would dominate health care policy and reform for the next 60 years. It pitted two contrary ways to think about health care-as a fee-for-service market commodity or something that should be provided to all regardless of ability to pay. This debate, along with cost containment, would be central issues for health care reform in the United States, with the debate structured along the lines of whether, despite what Truman said, universal coverage was or was not a form of socialism, despite arguments by Republicans such as Senator Robert Taft who made such an equivocation (Hillstrom, 2012: 295-266). Given the Cold War mentality in the United States and the fears of the USSR and communism, any policy initiative viewed as socialist would have little chance of passing. The question of how best to label health care reform and insurance coverage would remain tainted by the unfair socialism characterization, thereby creating a significant policy and partisan divide over the issue.

Prior to World War II there were few hospitals in the United States, the exception being those for the military. The Veterans Administration operated 91 hospitals, making it the largest health care system in the country (Starr, 1982: 348). Physicians performed many procedures and treatments in patient homes or in the small city or community hospitals that existed. There were also hospitals owned by NGO's especially those which were religious affiliated. The 1946 Hospital Survey and Construction Act, otherwise known as the Hill-Burton Act, initially made available $\$ 75$ million for five years. The Act was extended and between 1947 and 1971 nearly $\$ 4$ billion dollars in additional federal money was appropriated for new hospital construction (Starr, 198: 350). Money was made available based on demonstrated community need. Hill-Burton worked with the NGO the American Hospital Association to develop state-wide plans for the construction of hospitals and for the delivery of specific medical services. 
Hill-Burton was a major success in many ways. By the mid-1960s it had funded 8.200 projects that provided 349,318 hospital beds. Hill-Burton also required that any project or entity using its funds had to provide charity care in perpetuity (Schulte, 2009: 108). It was directly responsible for many communities having their own hospitals, and it certainly expanded medical services to many populations who otherwise might not have been served. The charity care provision also made health care more accessible. But Hill-Burton also created problems. First, the emphasis on hospital construction soon became costly. More hospitals meant that they would compete against one another for patients, since health care was being offered on a feefor- service basis. Hospitals made money by attracting patients and therefore became incentivized to offer more services (especially with insurance paying for them). Hospitals also centralized services and spent heavily on new, costly medical technologies. All this was expensive and created huge overhead costs that in turn drove up the cost of health care (Schulte, 2009: 108).

A second unintended consequence of Hill-Burton centred on the charity provision. Charity health care was a great concept, but "free" health care is not in fact free, except for the patient receiving the medical care. Hill-Burton did not clarify what the extent of charity care was to be, leaving open an erratic pattern of what services were delivered and to whom. Moreover, charity care did not mean that hospitals did not have costs - they did. Free health care to some had to be paid for by others - either by those insured or by public tax dollars. This in turn meant that either hospitals had an incentive not to tell patients about the Hill-Burton charity - leaving some patients who needed care without coverage - or treatments were provided, and costs had to be absorbed by the hospital, the insured, or by the taxpayers in some situations. It was an unsustainable business model.

\subsection{Johnson and the Expansion of Health Care Coverage}

The presidencies of Eisenhower and Kennedy saw little, if any, change in health care reform in the United States. In 1953, at the start of the Eisenhower presidency, approximately 71 million, or $44 \%$ of the population did not have health care insurance (Sullivan, 2006: 17). The Hill-Burton Act continued funding to encourage hospital construction and private sector unions negotiated for its members' health benefits with private employers (Starr, 1982: 310). Private insurance companies such as Blue Cross (originally founded in Dallas, Texas in 1929) expanded (Sullivan, 2006: 14-15). Otherwise, there were no real changes in health care policy until Lyndon Johnson became president following President Kenney's assassination in 1963. Estimates are that in 1963, 63 million, or 33\% of the population lacked health care insurance (Sullivan, 2006: 17).

Two major health care programs were adopted as part of Johnson's Great Society social programs. The first was the Medicare program that provided health care insurance for the elderly (age 65 or older). Eventually Medicare was extended to cover the disabled. Medicaid provided the same for the poor and indigent, especially those who were not working and therefore ineligible for employer funded health insurance programs. Under the original Medicaid and Medicare plans, any individual who met 
the eligibility rules for these plans would receive health care coverage for free. Both plans paid for health care on a cost or fee-for-service basis, allowing hospitals and other service providers to charge costs plus a 2\% profit (Schulte, 2009: 109). Medicaid and Medicare thus served several objectives. These programs extended health care insurance to populations who were not served by the private health insurance plans. By some estimates, by the early 1970s this reduced the number of individuals without health care coverage to $10-12 \%$ of the population (Starr, 2011: 5). Second, these two programs provided reimbursements to hospitals that had been losing money under the charity care provision of Hill-Burton. Thirdly, it reinforced the fee-for-service of health care model in the United States and also created incentives for health care providers to order additional medical services in an effort to maintain or secure profits.

Over time, Medicaid and Medicare have grown to become some of the largest expenditures and programs of the United States government. Medicare, when first implemented, was budgeted for $\$ 1.6$ billion, growing to $\$ 7.6$ billion by 1970 (Schulte, 2009: 127). By 2005, it had grown to an annual budget of more than $\$ 400$ billion, insuring by 2008 more than 45 million individuals. Conversely, Medicaid is a joint federal and state program where states receive federal money if they wish to participate in the program. All states participate in Medicaid, but not all, as shall be discussed below, have decided to expand participation to cover more individuals under the ACA. In 2006, Medicaid expenditures were $\$ 320$ billion, covering 55 million individuals in 2004 (Schulte, 2009: 131). These expenditures also paid for many elderly to stay in nursing homes.

Together, Medicaid and Medicare (along with Social Security-a federally administered retirement system created under President Roosevelt in the 1930s and funded by a tax on employees and employers), constitute the single largest set of expenditures by the federal government. These two programs are costly, and because of the basic fee-for-service reimbursement system employed, they have tended to encourage health care spending. Moreover, as the ranks of the number of elderly have increased along with life spans, Medicare spending has increased. Additionally, because of costs to private insured programs, as unemployment has increased, or as companies in the late twentieth and early twenty-first centuries have restructured and replaced full-time workers with part-time, or simply laid off workers or cut health benefits, more individuals have been added to Medicaid. The consequence of all of the above is that these two programs have become increasing more expensive and have helped drive up health care costs in the United States, even while they have also extended coverage. To a large extent, the twin goals of expanding coverage to more individuals while addressing cost containment have been the two major policy goals of health care reform from the 1970s to the present in the United States. 


\subsection{Health Policy from Nixon to Bush}

From the presidency of Richard Nixon (1969-1974) until the end of the presidency of the first George Bush (1989-1992), a variety of programs were adopted in an effort both to expand coverage and address costs.

Two pieces of legislation were adopted under Nixon in 1973. The first was the Health Planning and Resources Development Act which instituted a certificate of need (CON) (Schulte, 2009: 110). The CON required states to create planning agencies to coordinate health services and ensure that medical needs were being met by communities. A second goal of this legislation was to limit duplication or expansion of services driven by the Hill-Burton Act and Medicare and Medicaid. The idea here was that before a hospital could either expand or institute new services it would be required to secure a CON. It was unclear whether the CON process was successful, and it was repealed in 1987. Many states which had adopted their own CON also repealed their laws. The second law adopted in 1973 was the Health Maintenance Organization (HMO) Act. HMOs are entities (NGO's or for profit) that coordinate health services. They employ a combination of primary and preventive care to treat patients and they use a variety of case management and cost-containment mechanisms. HMOs often group physicians or medical services together, and they use referral services and monitoring of patients and expenditures to maintain costs. The HMO Act did not so much create HMOs as it made it easier for them to expand and flourish because of federal recognition.

In 1982, under President Reagan, Congress adopted the Tax Equity and Fiscal Responsibility Act (TEFRA). TEFRA was supposed to change the incentive structures for hospitals and medical providers. Instead of a system that encouraged increased profits through providing more (unnecessary?) services, TEFRA provided for set or predetermined fees based on the patient's diagnosis. Hospitals were then given incentives to treat the patient for this predetermined fee. In theory, the Act meant that medical providers would treat a patient in the least costly way possible because they could then retain excess reimbursement as profit or overhead. However, the Act created a different incentive that discouraged medical providers from offering services in an effort to save money.

Finally, in 1986 Congress adopted the Emergency Medical Treatment and Active Labor Act. This law outlined the rules hospitals must follow if a patient (including a woman in labor) shows up at an emergency room but is unable to pay. The law described the type of care all patients (especially the uninsured) must receive, when services may be refused, and what protocols must be followed when transferring patients to another medical facility. The purpose of the law was to prevent hospitals from refusing to treat patients without coverage and sending them to another hospital to absorb the treatment costs. 


\subsection{Clinton and Health Care Reform}

By the time President Bill Clinton became president in 1993 it was clear that the United States health care delivery and insurance system was unsustainable.

Consider first the number of individuals covered by insurance. In 1992, during the presidential election, the total population of the United States was 256,830,000. Of that population, $148,796,000$ million were covered by private insurance plans $(57.9 \%$ of the entire population) whereas another 66,244,000 were covered though Medicare, Medicaid, or the military ( $25.8 \%$ of the entire population). This left approximately $38,600,000$ or $15 \%$ of the population uninsured. This percentage had ticked up from $31,000,000$ or approximately $12.9 \%$ in 1987 (Starr, 2011).

Second, the percentage of the United States' gross national product (GDP) expended on health care had gone up dramatically. In $1960,5.1 \%$ of the US GDP was spent on health care (Sullivan, 2010: 20). In 1970, the US and Canada each spent about 7\% of their GDPs on health care. In 1971, Canada instituted a single-payer universal coverage program. By 1990, Canada spent $9 \%$ of its GDP on health care, the US 11.9\%, with 38.9 million uninsured (Starr, 2011: 84). Canada's single-payer system appeared to contain costs, especially by reducing administrative expenditures. America's growth in the percentage in how much of its GDP it would spend on health care would continue to grow such that by 2008 it would reach $18 \%, 50 \%$ greater as a percentage of the GDP in comparison to other Western European or OECD economies (Starr, 2011: 79). Simply put, compared to other OECD countries, the United States spent significantly more of its GDP on health care with Great Britain at $8.4 \%$ and Switzerland at $11.3 \%$ (Jacobs \& Skocpol, 2010: 21). Health care premiums for individuals, and costs for medical procedures in the US, are among the highest in the world (Sullivan, 2006: 42-43).

Third, the United States private insurance system is costly. Between 1987 and 1993, insurance premiums increased by $90 \%$ while salaries increased only by $28 \%$ (Starr, 2011: 79). Not a surprise, these premium increases were a powerful factor driving up the percentage of those who were uninsured. Finally, when compared to other countries, the health care outcomes of the US were not necessarily better as a result of all the money spent (Woolf \& Aron, 2013). In short, the US had a very expensive health care system with limited access and impact in terms of making the public healthier.

It was the above conditions that placed the issue of health care reform on the political agenda. This first occurred in 1991 in a special US Senate race in the state of Pennsylvania. Harris Wofford, a Democrat, won a come from behind victory by running on the campaign theme of universal health care (Starr, 2011: 79). His election was then credited with other Democrats winning in 1992, including presidential candidate Bill Clinton. Clinton and others made health care reform (access and affordability) among the prominent issues of the national elections that year. In the same year, incumbent President George Bush discussed the use of tax credits to extend 
health care coverage and there were also proposals in Congress to do the same (Starr, 2011: 80).

Bill Clinton was elected president in November 1992. On January 25, 1993, just days after he was sworn into office, President Clinton announced the creation of the President's Task Force on National Health Care Reform, chaired by his wife, future senator, Secretary of State and Presidential Nominee Hilary Rodham Clinton. On the agenda were a series of possible reforms, including the Bush suggestion of tax cuts to extend coverage; a single-payer universal coverage system (similar to that found in Canada) which had been repeatedly advocated by Senator Ted Kennedy; a pay-orplay system, which required employers to provide health care coverage or pay into a public program; and, a managed care system. A managed care system was one where consumers would have a choice of competing managed care plans. The managed care plans would require insurers to offer standard insurance packages; would prevent insurers from excluding coverage (or setting rates) based on an applicant's background or health history (i.e., pre-existing medical conditions); and, they would also encourage other mechanisms to encourage savings by requiring individuals to assume responsibility for maintaining their health (Starr, 2011: 81-86).

On September 22, 1993 President Clinton gave a speech to Congress declaring a need to reform the American health care system. He basically proposed a managed competition system, delegating to his task force 100 days to draft a formal proposal to be sent to Congress. He directed that his plan should have both universal coverage and cost control mechanisms in it. Initially there was strong public support for his proposal but that support rapidly evaporated for many reasons.

First, while Democrats initially supported it, Republicans increasingly grew wary, fearing a significant government takeover of the economy. There was also the criticism that drafting of the bill was done by the White House and in relative secret, thereby undermining congressional buy-in for the law. Third, a decline in President Clinton's political popularity, brought on by allegations of illegal behavior by him and his wife before he was president and still governor of Arkansas, also distracted attention from health care reform (Starr, 2011: 94-95). There were additional allegations that the reforms that Clinton wanted were simply too broad in scope, thereby lacking support necessary to achieve reform. The reforms would impact approximately $12 \%$ of the economy. The simple scale of the reforms scared many.

In addition, one can cite many specific groups that either for ideological or economic reasons opposed the changes. The AMA, for example, opposed many of the cost containment features, fearing they would adversely affect physician income. Tax proposals to finance the reforms ran into public and Republican opposition. Indeed, businesses and many labor unions were generally opposed to any new taxes or proposals that affected them (Starr, 2011: 115). Consumers perceived the reforms would adversely affect their ability to choose doctors or seek medical care. Finally, a combination of Democratic Party disunity, Republicans making opposition to health care reform a major 1994 campaign issue, and a series of well-crafted political ads equating the Clinton reforms with socialized medicine, all helped to defeat the Clinton 
plan. Criticisms of President Clinton's plan also led to significant losses for the Democrats in the 1994 Congressional mid-term elections (Pfiffner, 1994). Health care reform was effectively dead and with Republicans in control of Congress for most of the next decade (and then the presidency with George Bush starting in 2001), issues such as tax cuts and government spending dominated the agenda. However while there was no reform to health care, the underlying problems such as affordability (individual and as a percentage of the GDP) persisted, as did concern about access and outcomes.

\subsection{Health Care Reform 1996-2008}

Despite the collapse of the broader Clinton health care initiative, smaller reforms did take place under both his presidency and that of his successor George W. Bush. Most of the reforms could be described as modest.

In 1996, for example, Congress and the president agreed to the Health Insurance Portability and Accountability Act (HIPPA). HIPPA is mostly noted in the United States for protection of patient and employee medical records, that is to say, confidentiality. HIPPA's privacy provisions mandated standard procedures for protection, storage and transmission of medical data. But, the Act also sought to address another problem, namely the difficulty people face when leaving one job for another and the fear that a new employer plan might exclude them from coverage because of some pre-existing medical condition. HIPPA forbid new employers and their health insurers from discriminating against new employees in the provision of health benefits. Employers were also required to give new employees credit for time in previous employment if there was a waiting period before eligibility for benefits. All of these provisions were meant to facilitate, or at least not discourage, individuals from leaving one job and taking another for fear that they would lose medical benefits (Schulte, 2009: 115-117).

The State Children's Health Insurance Program (SCHIP) was adopted in 1997. SCHIP built on the existing Medicaid program and extended health care coverage to uninsured low-income children then ineligible for Medicaid. SCHIP worked by providing federal dollars to states to extend Medicaid coverage. States were free to refuse SCHIP money and extend coverage, but the amount of money available to states for this program was generous compared to the regular matching Medicaid program, and the idea of covering children who needed health care was politically popular (Schulte, 2009: 134). Given that the year before the federal government had adopted major welfare reform that resulted in many families no longer being eligible for public health care programs, SCHIP was seen as a way again to encourage individuals to seek employment. But despite support for the program, when Congress in 2007 sought to expand SCHIP to cover more children, President Bush vetoed it, instead forcing a simple reauthorization of the existing program (Starr, 2011: 177).

The final federal initiative prior to the election of President Obama was adoption of prescription drug coverage for elderly on Medicare. When Medicare was originally adopted the law did not provide for prescription drug coverage, leaving it up to the elderly to either buy drugs on their own or to purchase separate supplemental health 
care plans to cover them. In the 2000 presidential race between Clinton's vicepresident $\mathrm{Al}$ Gore and George Bush, the former called for prescription drug coverage for all elderly, extending SCHIP to cover all uninsured children, and reducing the eligibility age of Medicare from 65 to 55 (Starr, 2011: 146-147). Bush was elected, in part because of his support from older voters, and he eventually endorsed the addition of drug coverage to Medicare. Thus, in 2003 The Medicare Prescription Drug, Improvement, and Modernization Act was signed into law. It committed the federal government to an additional $\$ 400$ billion in government spending over the next ten years. The Act gave senior citizens a variety of options on how to purchase additional insurance to obtain prescription drug coverage. For many, the options seemed confusing. For the economy and health care reform, it added to the budget deficit, did little to encourage cost containment, and further increased the overall projected GDP spending on health care in the United States.

\subsection{Mitt Romney and Massachusetts Health Care Reform}

A significant amount of health care reform in the United States in the decade or so before Obama became president took place at the state level. Consistent with an American myth or belief that states are laboratories of democracy, the federal government in the 1990s and into the twentieth-first century often gave states waivers from federal regulations to encourage them to experiment with different ways to provide health care coverage for their citizens. Among the most notable example was Massachusetts, which in 2005 became the second state to move toward universal health care insurance for all its citizens (Hawaii was the first state to do this in 1974).

Massachusetts is one of the most politically liberal and Democratic states in America. It is home to the Kennedys, with former Senator Ted Kennedy defining his entire career as an advocate for universal health care insurance for all Americans. Massachusetts had also been an early and important innovator in health care reform. In 1988, then Governor Michael Dukakis signed legislation requiring employers to provide insurance to employees or pay a special tax. The law also provided for health care for students and the unemployed. The bill's enforcement was delayed by the next governor and state legislature, but still this represented a step toward expanding coverage (Starr, 2011: 166).

In 2004, Republican Mitt Romney became the governor of Massachusetts and presided over a state legislature controlled by the Democratic Party. Working with both the Heritage Foundation (a conservative think tank), Senator Ted Kennedy, and the Bush administration in Washington, Governor Romney was architect of a health care law that included several features. First, it contained a Medicaid waiver to allow the state to depart from federal health law requirements. Second, it required employers to provide insurance to their employers or pay a fee to the state. Third, it included an individual mandate, calling for individuals to purchase their own health insurance (if they did not receive it through work or already have it) or demonstrate an ability to pay for health care. Fourth, for individuals who could not afford to pay for their own insurance, it either expanded eligibility for Medicaid, SCHIP, or provided tax credits or subsidies, and it created a health care exchange for individuals to shop for 
insurance. The plan also expanded coverage and eligibility for the state MassHealth, the state health care plan (Starr, 2011: 167-174).

The Massachusetts health care law is notable for several reasons. First, it rejected the idea of a single-payer government financed system in lieu of the use of private insurance and employer and individual mandates. Second, the law seemed to have an immediate impact in lowering the uninsured rate in Massachusetts. Third, the law did not really have any provisions to address cost containment. Finally, and perhaps most importantly, the Massachusetts plan was in many ways the basis of eventually what the Obama administration would support, and which would pass as the Affordable Care Act in 2010 (Hillstrom, 2012: 616; Starr, 2011: 172-174).

Barack Obama and the Affordable Care Act

\subsection{Elections and the Congressional Debates}

More than a generation after the failed efforts by the Clinton administration to pass health insurance reform, the basic problems underlying health care persisted. According to the US Census Bureau, in 2008 15.4\% or 46.3 million individuals in the United States lacked health care insurance (Census, 2009: 20). Two-thirds of the American public was covered by private insurance with a total of $58.5 \%$ receiving it through their employer (Census, 2009: 20). Not a surprise, young adults, people of color and the working class making too much money to be eligible for government provided or subsidized insurance were the most likely to be without coverage. Additionally, by 2008 the United States was spending 16.6\% of its GDP for health care, or approximately $\$ 2.4$ trillion. Projections were that this government spending would increase to more than $20 \%$ of the GDP by 2018, in part as a consequence of the aging Baby Boom generation. Insurance premium costs were also increasing in percentages far exceeding the rate of inflation or the general cost of living, resulting in an affordability crisis for both the United States as a whole and individuals and families. According to the Kaiser for Democrats health insurance was the number one concern in 2007 (Starr, 2011: 182).

Health care insurance reform thus became a major issue in the 2008 Democratic Party presidential primary (Jacobs \& Skocpol, 2010: 30-31). Former senator and 2004 vicepresidential candidate John Edwards ran on the promise of supporting an individual and employer mandate, expanding state health care exchanges and eligibility for Medicaid, and expansion of a federal government health care exchange (Starr, 2011: 182-183).

Former first lady and then presidential candidate and Senator Hilary Clinton too called for more universal coverage, with her plan emphasizing expansion of Medicaid for the poor, tax credits and subsidies to allow for individual purchases, some health care exchanges, a modest creation of a government health care insurance system, and an employer mandate, but only for larger companies, as well as an individual mandate (Starr, 2011: 185-186). Senator and then presidential candidate Barack Obama did not originally embrace the individual mandate, instead opting to criticize Clinton for her 
position on it, arguing she was forcing people to buy insurance when they could not afford it. Obama took a more moderate approach, opting for expansion of coverage for children. He also advocated for expansion of Medicaid, some form of an employer mandate and some form of a national health care exchange. His plan was vague on critical details. Over the course of the Democratic presidential primaries his views evolved, and Obama eventually seemed to endorse the Clinton individual mandate. On the Republican side, Senator and presidential candidate John McCain called for tax incentives and tort or malpractice reform to address insurance coverage, but largely health care was not a major topic of debate for Republicans (Jacobs \& Skocpol, 2010: 36-37).

Not only did Obama defeat McCain in 2008 in the presidential election, but the Democrats also achieved gains in the Congress. They picked up enough seats in the House to have a commanding majority and eventually in the Senate they secured 60 votes - enough to guarantee them sufficient votes to bypass a potential filibuster or a blocking of a vote by Republicans. As president, Obama was immediately preoccupied with the 2008-9 global economic crash. His attention first turned to passing an economic stimulus bill to help the economy. The president turned health care reform essentially over to Congress, perhaps leaning the lesson of the failed Clinton reforms which had the White House write the legislation (Jacobs \& Skocpol, 2010: 56). This was not the only difference from 1993.

Unlike under Clinton, many of the major health care players, such as the pharmaceutical industry, the private insurance companies, and the AMA eventually supported the reforms. In many ways these industries were then being economically squeezed or realized that the addition of millions of additional insured customers would be profitable to them, or that they would become the beneficiaries of special rules that would inure to their benefit (Jacobs \& Skocpol, 2010: 70-71). For example, the pharmaceutical industry stood to make billions of dollars from the new customers it would receive, as well as some protections from the use of generic drugs. Bringing these groups into negotiations thus eased some of the opposition. Second, Congress was even more polarized ideologically along party lines than was the case in 1993, with Republicans firmly opposed and opposing the eventual passage of the Affordable Care Act.

Third, most prominently or publicly initially, President Obama largely left it up to Congress to draft and develop the health care legislation. This posed a problem when some Democratic senators from Republican-leaning states such as Nebraska and Louisiana were unwilling to support health care reform. Obama seemed to provide little leadership on this issue, with many worried by mid-2009 that the law was going nowhere. Finally, Senator Ted Kennedy's death in 2009 and his replacement by Republican Senator Scott Brown, changed the political dynamics in a couple of significant ways (Hillstrom, 2012: 622). First, Kennedy had been the leading figure advocating for health care reform and single-payer for $40+$ years and his departure created a power vacuum or void in terms of an advocate for reform. Second, Kennedy's death also meant the Democrats lost their super-majority status in the Senate, meaning Republicans could block votes on reform. However, using a variety 
of governmental procedures and special Senate rules, the Affordable Care Act (ACA) was passed in 2014 .

So why did the ACA pass? Why success on health care reform this time as opposed to other efforts since the Harry Truman speech in 1946 calling for it? There is no one reason. Some had to do with the mounting costs of health care to businesses and families. Part of it was due to the buy in by major health care industry players. Part of it was also due to Obama's and the Democrats' huge victory in 2008. Part of it also could be attributed to the fact that Obama and Democrats eventually put more effort on this reform than others, such as addressing the environment (Starr, 2011: 236-238). Finally, the relative modesty of the ACA, relying significantly on use of private insurance, employer coverage or mandates, a conservative individual mandate, modest expansion of current government programs, and an overall continued embracing of a mostly market-based approach to health insurance all could be counted as factors explaining its eventual passage.

\subsection{Major Provisions of the Affordable Care Act}

The final version of the Patient Protection and Affordable Care Act (Public Law 111148) contained several provisions to extend health care to cover the 47 million Americans who did not presently have insurance. The law is a complex package of many provisions that combine government and private insurance systems and market incentives to expand the quality and overall coverage and access to health care services. The ACA also contains provisions to address costs. The main provisions or points of the law can be grouped around a series of provisions which can be labeled as the individual, employer, and state of Medicaid mandates (Kaiser, 2011).

First, the ACA has an individual mandate requiring all US citizens and legal residents to maintain qualifying health care coverage. By "qualifying" the law specifies certain conditions and services to be provided in the policy. Second, the ACA does not require undocumented aliens or individuals who are not legally residing in the country to maintain health insurance. The estimates are that this number is approximately 12 million individuals. Others, such as those incarcerated, Native Americans, or who object on religious grounds, are also exempt. These exempt individuals may or may not seek medical services and they may or may not be able to or be eligible to purchase health insurance. Individuals required to have health insurance may meet the requirement by receiving it though their workplace or from the government if they are eligible for Medicare or Medicaid. Individuals who do not have health insurance are required to pay a tax penalty. Individuals who cannot afford to purchase health insurance receive subsidies to buy a plan.

The second provision to extend coverage is an employer mandate. Companies with 50 or more employees are required to provide health insurance for their workers or pay a fine of $\$ 2,000$ per employee. Businesses with under 50 employees are exempt from this mandate and those with more than 200 employees must automatically enroll employees into a plan if they have it. Small businesses (25 or fewer employees) are provided tax incentives or subsidies to provide health care insurance. 
Third, states are provided incentives to expand Medicaid coverage to individuals under the age 65, who quality based on income. States receive additional Medicaid funding if they expanded eligibility, but if they did not, they would not receive this additional money and would also face a loss of any future Medicaid money. The ACA also mandated the creation of health care exchanges by states. These exchanges are places where individuals and business can shop for and purchase health care insurance. The idea behind the exchanges is to create a central location where purchasers can locate qualified health insurance plans and presumably shop for the best priced plans that meet their needs. Between 2013 and through 2017, various rules regarding how the exchanges would operate, who could use them, and the types of plans that would be available (such as multi-state plans) would eventually kick in or change. The exchanges would be operated by the individual states unless they decided not to in which case the federal government would operate exchanges on behalf of such states.

In addition to these three mandates to expand coverage, the ACA also regulates the content and the terms and conditions of the health care plans to be offered. Adult children are allowed to stay on their parents' private insurance plan until age 26 . Insurance companies are not permitted to deny individuals coverage for pre-existing illnesses. Four levels of health plans plus a catastrophic illness plan must be offered though the exchanges. Each of these plans must have varying levels of coverage and deductibles or out-of-pocket expenses for purchasers. Additionally, states are permitted to prohibit plans in the exchanges from covering abortions.

Finally, the ACA imposes a series of cost containment rules. These included a simplification of rules to determine eligibility. There are also new rules for reducing or restructuring Medicare payments to hospitals and other providers, creating innovation centers to explore new ways to fund or save money on health administration and medical treatment. Finally, there is a stronger emphasis on using generic drugs and developing programs to combat waste and fraud through the development of new compliance procedures and reporting systems.

In terms of efforts to improve health care outcomes, money is committed to performing comparative research in ways to improve treatment and care. Additionally, health care plans are required to fund various preventive or wellness care programs.

The law budgeted approximately $\$ 800$ billion to pay for the ACA. Of that, $\$ 500$ billion would come from cuts in existing health care spending, such as for Medicare. The additional $\$ 300$ billion would come from various taxes on items such as medical devices, the so-called Cadillac or high-benefit private plans, elective cosmetic surgery, certain pharmaceutical manufacturers, and through the elimination of current tax deductions for some medical and health expenses. According to the Congressional Budget Office's (CBO) initial projections, the ACA will result in 32 million individuals receiving health insurance. Overall insurance coverage for Americans will move from its current $83 \%$ to $94 \%$ by 2019 (Congressional Budget Office, 2010: 21; Jacobs \& Skocpol, 2010: 122). The CBO estimated also that the ACA would have 
some impact on reducing the federal budget deficit by $\$ 143$ billion by 2019 (Congressional Budget Office, 2010: 2).

\subsection{Implementation History}

Initial implementation of the ACA got off to a difficult start. It was plagued by political, legal and administrative problems that have had various impacts and results on the continued viability of the law.

Perhaps the most significant variables impacting the efficacy of the ACA has been both its political opposition and lack of initial public support for the law. For example, right after the passage of the ACA, public opinion was divided in support (40\%) and opposition (54\%) (Starr, 2011:271). More significantly, 75\% of Democrats supported the law while $80 \%$ of Republicans opposed it. The ACA effectively passed without any Republican Party votes in Congress and support and opposition toward the law has become a politically polarizing issue. However, by the end of 2018, 53\% supported the ACA and only 40\% opposed it (Kaiser Family Foundation, 2018a). Public opinion had flipped, even if there was still strong partisan opposition to the ACA with $80 \%$ of Democrats supporting it and $76 \%$ of Republicans opposed.

In 2009, a very conservative political movement known as the Tea Party formed in the US, taking as one of its major positions opposition to the ACA and calls for its repeal (Hillstrom, 2012: 617-618; Jacobs \& Skocpol, 2010: 76-77). The Tea Party moved into the Republican Party and politically recruited candidates to oppose the ACA. Public opinion opposition to the law was also significant, as noted above, and the 2010 mid-term congressional elections were in part cast as a referendum on the ACA. Those elections saw the Democrats lose control of the House of Representatives and also lose seats in the US Senate. In 2012, the Republican Party again made the ACA a major campaign issue, but was less successful in using it as a campaign theme. This was due, in part, to the fact that their presidential candidate, Mitt Romney, was unable to articulate this theme as an issue because in many ways his health care reform law in Massachusetts was the model for Obama's. Romney also proved to be a less than stellar candidate.

The significance of the political opposition to the ACA has had at least four results. First, the Republican controlled House of Representatives has voted nearly 50 times to repeal the ACA. Opposition to the law has impacted many congressionalpresidential negotiations on issues from taxes, the budget, and debt reduction, and it led to a partial government shutdown in the US in 2013. Second, the polarization over the ACA has precluded the president from going back to Congress to seek changes in the law that might be necessary or discovered as a result of implementation. This has meant that the president has used his rule-making authority to make some changes, raising charges or allegations that he is acting illegally or improperly by bypassing the Congress. In the summer of 2014, the Republican House of Representatives voted to authorize a lawsuit against the president challenging his implementation of the ACA. Such charges have only added to the partisanship polarization surrounding the law. 
Third, the political polarization led to a scenario where only 14 states and the District of Columbia have created their own health care exchanges. Republican governors and Republican dominated state legislatures have generally been unwilling to run their own health care exchanges, leaving it up to the federal government to do that. Such partisan opposition to the ACA and refusal on the part of many states to create their own exchanges was not anticipated and it forced the federal government into a situation where it did not expect to have to operate the vast majority of the exchanges and to become a prime implementer of the law. The ACA really anticipated federalstate cooperation and in many cases it did not happen.

Fourth, partisan opposition to the ACA has also led to numerous legal attacks (Starr, 2011: 276; Jacobs \& Skocpol, 2010: 154-155). Led by state Republican attorney generals or governors, one argument was that the federal government lacked the constitutional authority to mandate that individuals purchase health insurance. A second argument was that the federal government lacked the authority to require states to expand Medicaid coverage. In National Federal of Independent Businesses $v$. Sebelius (2012), the Supreme Court held that while the individual mandate exceeded the federal government's power under the Commerce Clause, it did uphold the mandate as a valid exercise of power under the national government's tax and spend authority. Specifically, the Court held that Congress had the power to impose a tax on individuals who were insured yet refused to purchase health insurance. However, the Court also ruled that the federal government could not penalize states if they did not expand Medicaid coverage by withholding all Medicaid funding. The significance of this ruling was that it meant that states effectively could refuse to expand Medicaid coverage to more uninsured individuals. In many states under Republican Party control, this is exactly what has occurred, thereby blunting the number of individual's that the ACA will cover.

A second challenge to the ACA came from businesses contending that it violates their First Amendment Free Exercise of Religion Rights to be required to pay for health insurance policies that provide for birth control or contraception for women. Lower federal courts were divided on this issue and in Burwell v. Hobby Lobby Stores (2014), the Supreme Court ruled that the contraceptive mandate under the ACA violates the religious rights of closely-held corporations because they are persons under the Religious Freedom Restoration Act.

A third legal challenge addressed that aspect of the ACA that allows for subsidies to low income individuals who purchase health insurance through the federal health care exchanges. Some have argued that the language of the ACA only allows for subsidies in cases where states run a health care exchange. The Supreme Court rejected that claim in King v. Burwell, 576 U.S. (2015).

The partisan opposition to the ACA in part led Donald Trump to win the presidency on a campaign promise to repeal the law. While that did not happen, in 2018 Congress, starting in 2019 , reduced the fine for not having insurance to $\$ 0$, effectively removing the mandate. It is too early to tell what impact this will have on enrolment. Yet, repeal of the fine for the mandate also led a federal judge to strike down the entire ACA in 
late 2018, leaving its constitutional fate to be determined perhaps by the Supreme Court (Kaiser Family Foundation, 2018b).

In addition to legal challenges, the ACA has faced other problems. At both the state and more notably at the federal level, the roll out and implementation of the websites for the health care exchanges have been fraught with many problems. The websites were difficult to navigate, contained incomplete information, or otherwise consisted of bad design making it difficult for individuals to use them. When the health care websites and exchanges premiered on October 1,2013, they were criticized as failures and initial enrollments in health insurance was slow. Originally, the Obama Administration had anticipated 7 million enrollees by April 1, 2014. That was then revised down to 6 million. In the end, approximately 8 million did enroll, but it is unclear how many were previously uninsured or simply switched insurance. However, after these initial problems, by 2018 enrollment peaked at 11,750,000, falling in 2019 to $8,411,000$ due to the drop of the fine for the individual mandate (Kaiser Family Foundation, 2018c). Additionally, by the end of 2017, 91.2\% of those in the US had health insurance, leaving 28.5 million without coverage for part of that year. This was down from $15.4 \%$ or 46.3 million individuals uninsured in 2008. The ACA had appeared to succeed in its goal in reducing the percentage and number uninsured (Bercik, Hood \& Barnett, 2018).

The difficultly with the federal health care exchanges has also led to a criticism that the Obama Administration was largely inept or politically weak in rolling out the ACA. One example is that when candidate and later President Obama was trying to sell passage of the law, he stated several times that the law would not require individuals to give up their existing coverage. His statement was that "if you like your existing policy you can keep it." The problem was that many of the existing policies were no longer legal or meet the minimum requirements under the ACA. In 2013, many individuals received notice of policy cancellations and Obama was accused of lying. In response to criticism regarding these cancelled policies the President issued a moratorium and allowed individuals to continue with existing policies for another year. Obama also delayed enforcement of several of the employer mandates so that they would not take effect after the 2014 elections (McCardle, 2014).

Beyond all of the implementation problems, there are questions regarding whether the ACA will achieve its objectives. This is especially the case given that many states never extended coverage through the Medicaid expansion or that once Donald Trump was elected, the penalty for the individual mandated was repealed, leaving open how effective expansion of coverage will be longer term. As noted above, while the percentage and number of uninsured persons has gone down through 2017, the effective repeal of the individual mandate raises questions regarding whether that trend will continue. Second, there have also been mixed signals regarding cost projects. At the micro or individual premium level, the ACA reduced premiums and out-of-pocket spending for lower income individuals but increased them for individuals earning higher incomes (Goldman et al., 2018). At the macro level, there is little evidence that the ACA changed the cost curve or reduced health care spending in the US (Weiner, Marks \& Pauly, 2017). Some argued this was the case because the 
ACA never really included significant cost controls (White, 2013). Moreover, the ACA did not address the demographic issues surrounding the increased health care costs associated with an aging American population, and it did little to address to the shortage of insurers available to cover rural areas, which became a major problem in 2016 .

Lastly, it remains to be seen whether the law will improve the health of Americans (Fairfield, 2014). However, a review of the literature suggests improved self-reported health among those insured (Kaiser Family Foundation, 2018d), but macro or national evidence of the health outcome impact of the ACA is still not clear.

\section{Conclusion}

The United States health care system developed incrementally and in a piecemeal fashion over nearly 150 years. Its history includes a series of institutions, actors, and interests that created a crisis by the time of the election of Barack Obama in 2008. The passage of the Affordable Care Act was supposed to provide health care for all, address costs and improve health outcomes for all. The implementation history of the ACA has resulted in some progress for access to health care, but there is less evidence it has led to cost reduction, and whether it has led or will lead to better health care outcomes is a major imponderable. However, partisan disagreement over the ACA impacted its implementation and it is not clear moving forward if there is a consensus to fix, repeal or replace it.

\section{References}

Berchick, E. R., Hood, E. \& Barnett, J. C. (2018) Health Insurance Coverage in the United States: 2017 (Washington, D.C.: U.S. Census Bureau).

Buchanan, L., Fairfield, H. \& Yourish, H. (2014) Rating a Health Law's Success, New York Times (May 19, 2014), retrived from https://www.nytimes.com/interactive/2014/05/19/health/rating-a-health-lawssuccess.html_(December 19, 2018)

Congressional Budget Office (2010) H.R. 4872, Reconciliation Act of 2010 (Final Health Care Legislation), (March 20, 2010)

Goldman, A. L. et al. (2018) Out-of-Pocket Spending and Premium Contributions After Implementation of the Affordable Care Act, JAMA Internal Medicine, 178(3), pp. 347355, doi: 10.1001/jamainternmed.2017.8060.

Hillstrom, K. (2012) U.S. Health Policy and Politics: A Documentary History (Los Angeles, CA: Sage).

Jacobs, Lawrence R., \& Skocpol, T. (2010) Health Care Reform and American Politics: What Everyone Needs to Know (New York: Oxford University Press).

Kaiser Family Foundation (2011) Summary of the Affordable Care Act, retrieved from http://kaiserfamilyfoundation.files.wordpress.com/2011/04/8061-021.pdf (August 8, 2018.)

Kaiser Family Foundation (2018a) 6 Charts About Public Opinion On The Affordable Care Act, (December 19, 2018), retrieved from https://www.kff.org/health-reform/poll-finding/6charts-about-public-opinion-on-the-affordable-care-act/ (January 17, 2019).

Kaiser Family Foundation (2018b) How Repeal of the Individual Mandate and Expansion of Loosely Regulated Plans are Affecting 2019 Premiums, (October 26, 2018), retrieved 
from https://www.kff.org/health-costs/issue-brief/how-repeal-of-the-individualmandate-and-expansion-of-loosely-regulated-plans-are-affecting-2019-premiums/ (January 17, 2019).

Kaiser Family Foundation (2018c) Marketplace Enrollment, 2014-2019, retrieved from https://www.kff.org/health-reform/state-indicator/marketplace-enrollment-2014$2017 /$ ? currentTimeframe $=0 \&$ sortModel $=\% 7 \mathrm{~B} \% 22$ colId $\% 22: \% 22$ Location $\% 22, \% 22 \mathrm{~s}$ ort\%22:\%22asc\%22\%7D (January 17, 2019)

Kaiser Family Foundation (2018d, March 28) The Effects of Medicaid Expansion under the ACA: Updated Findings from a Literature Review, retrieved from https://www.kff.org/medicaid/issue-brief/the-effects-of-medicaid-expansion-underthe-aca-updated-findings-from-a-literature-review-march-2018/ (January 17, 2019).

McCardle, M. (2014) Will Obama Ever Enforce His Health Law?, Politics in Minnesota, (March 10, 2014), pp. 5.

Pfiffner, J. P. (1994) President Clinton's Health Care Reform Proposals of 1994, retrieved from http://www.thepresidency.org/storage/documents/President_Clintons_Health_Care_R eform_Proposals.pdf (August 8, 2014)

Schulte, M. F. (2009) Health Care Delivery in the U.S.A.: an introduction (New York: CRC Press).

Starr, P. (2011) Remedy and Reaction: The Peculiar American Struggle Over Health Care Reform (New Haven: Yale University Press).

Starr, P. (1982) The Social Transformation of American Medicine (New York: Basic Books).

Sullivan, K. (2006) The Health Care Mess: How We Got Into It and How We'll Get Out of It (Bloomington, Indiana: Author House).

White, J. (2013) Cost Control After the ACA, Public Administration Review, 73(S1), pp. S24S33, doi: 10.1111/puar.12108.

Weiner, J., Clifford, M. \& Mark, P. (2017) Effects of the ACA on Health Care Cost Containment: What has the ACA done to "bend the cost curve"? Fourth and Final in a Series on the Impact of the ACA, retrieved from https://di.upenn.edu/brief/effects-acahealth-care-cost-containment (January 17, 2019)

Woolf, S. H. \& Laudan, A. (2013) U.S. Health in International Perspective: Shorter Lives, Poorer Health (Washington, DC: The National Academies Press). 
MEDICINE, LAW \& SOCIETY

D. Schultz: The Implementation and Evaluation of the United States Affordable Care Act 